Meta

Journal des traducteurs

Translators' Journal

\title{
On Translating Metaphor
}

\section{Antonia Alvarez}

Volume 38, numéro 3, septembre 1993

URI : https://id.erudit.org/iderudit/001879ar

DOI : https://doi.org/10.7202/001879ar

Aller au sommaire du numéro

\section{Éditeur(s)}

Les Presses de l'Université de Montréal

ISSN

0026-0452 (imprimé)

1492-1421 (numérique)

Découvrir la revue

Citer cet article

Alvarez, A. (1993). On Translating Metaphor. Meta, 38(3), 479-490.

https://doi.org/10.7202/001879ar

\section{Résumé de l'article}

La métaphore constitue l'un des principaux problèmes auxquels fait face le traducteur littéraire. Par son importance et sa fréquence, elle s'impose comme un élément essentiel du processus traductionnel. Mais les théoriciens lui ont accordé peu d'attention, probablement à cause des difficultés inhérentes à l'élaboration d'une théorie de la traduction des métaphores. Le présent article se contentera donc défaire des généralisations sur ce type de traduction. Le cadre d'analyse adopté est un texte d'Angela Carter, la métaphore étant au coeur du processus créatif chez cet auteur. d'utilisation que vous pouvez consulter en ligne.

https://apropos.erudit.org/fr/usagers/politique-dutilisation/ 


\title{
ON TRANSLATING METAPHOR
}

ANTONIA ALVAREZ

Universidad Nacional de Educación a Distancia, Madrid, Spain

\begin{abstract}
Résumé
La métaphore constitue l'un des principaux problèmes auxquels fait face le traducteur littéraire. Par son importance et sa fréquence, elle s'impose comme un élément essentiel du processus traductionnel. Mais les théoriciens lui ont accordé peu d'attention, probablement à cause des difficultés inhérentes à l'élaboration d'une théorie de la traduction des métaphores. Le présent article se contentera donc de faire des généralisations sur ce type de traduction. Le cadre d'analyse adopté est un texte d'Angela Carter, la métaphore étant au coeur du processus créatif chez cet auteur.
\end{abstract}

\begin{abstract}
One of the main difficulties a literary translator has to face is metaphorical language. In view of its importance and frequency it constitutes an essential element in translation process, but it has received little attention by translation theorists, perhaps because of the obstacles to reach some kind of theory of metaphor translation. That's why we'll try to make some generalizations on translating metaphor, using as a frame to develop our analysis a text by Angela Carter, since metaphor is a true, recurrent medium for her artistic vision of literature. As most critics say, in her baroque use of imagery, metaphor is at the heart of Carter's creative process and has a special claim for the reader's attention.
\end{abstract}

\section{AN ATTEMPT TO DEFINE METAPHOR}

\section{A Revision of Critical Approaches}

The line between literal and metaphorical language is not clear since some metaphors are in the process of dying and becoming part of common language. In Eva Feder Kittay's words, "because of the dynamic inherent in language the metaphorical becomes literal and the language becomes metaphorical." (1987:22) This is the case in the example:

(1) "the hair was dyed as a brave canary yellow" (el pelo, teñido de un osado amarillo canario); the metaphorical term canary collocated with yellow is lexicalized since this is why we refer to a specific colour.

Other example of dead metaphor is:

(2) "Her shoes are all that anchor her to the ground" (Eran los zapatos lo único que la anclaba al suelo). Both examples are also lexicalized in Spanish.

Lakoff and Johnson differentiate the literal from the metaphorical use of language: we understand experience metaphorically "when we use an expression from one domain of experience to structure experience in another domain," for instance, the original metaphor:

(3) "the hair... giving the general impression of a very expensive ice-cream sundae" (el pelo... daba la impresión de un enorme y carísimo helado de crema);

Language which" is literal "speaks of how we understand our experience directly, when we see it as being structured directly from interaction with and in our environment." (1980: 230) 
Metaphorical talk, says Cooper (1986: 140), "effects a familiarity or 'intimacy" between speakers, and between them and their work;" we may utter a metaphor to stimulate an image:

(4) "With her hair coiled in loop upon serpentine loop on her head" (con el cabello enroscado en volutas serpentinas),

to provoque an interesting comparison:

(5) "An old creature with hair like a nest of petrified snakes" (Una anciana criatura con un peinado que parecía un nido de serpientes petrificadas),

or to register a beautiful turn of phrase:

(6) "the walls of this passage shuddered and sighed at first almost imperceptibly, so that I mistook it for my own breathing" (las paredes del pasadizo se estremecian y susurraban, casi imperceptibles al principio, de modo que pensé que eran los sonidos de mi propia respiración). The inanimate noun walls is personified.

Earl R. Mac Cormac defines metaphorical language as that which "forces us to wonder, compare, note similarities; it seeks to create new suggestive ways of perceiving and understanding the world." (1985: 78) A good example would be this extremely poetic metaphor:

(7) "The rocks between which I am pressed as between pages of a gigantic book seemed to me to be composed of silence; I am pressed between the leaves of a book of silence" (Las rocas que me comprimen como las páginas de un libro gigantesco me parecen compuestas de silencio; estoy aplastada entre las hojas de un libro de silencio).

In Aristotle's terms, metaphor is "the mark of genius" (Poetics 1459a), which can be illustrated with the example:

(8) "As she swaycd in shoes so high... they transformed her into a bird plumed with furs" (Cimbreándose sobre aquellos zapatos tan altos... se transformaba en un pájaro con plumaje de pieles). There is also a personification of shoes, and the adjectival phrase plumed with furs is transformed into a prepositional phrase con plumaje de pieles since there is no syntactical equivalence in Spanish.

Menachem Dagut defines metaphor as "an individual creative flash of imagination fusing disparate categories of experience in a powerfully meaningful semantic anomaly." (1987: 77) In the following expressive, totally original metaphor:

(9) "Reading is just as creative an activity as writing and most intelectual development depends upon new readings of old texts. I am putting new wine in old bottles, especially if the pressure of the new wine makes the old bottles explode." (Carter 1983: 69) The semantic field to which wine and bottles belong is, of course, a different one from writing; thus, disparate categories of experience are fused.

"The Platonist and the positivist," according to Richard Rorty, "share a reductionist view of metaphor: they think metaphors are either paraphrasable or useless for the one serious purpose which language has, namely, representing reality. By contrast, the romantics have an expansionist view: they think metaphor is strange, mystic, wonderful. Romantics attribute metaphor to a mysterious faculty called imagination, a faculty which they suppose to be at the very centre of the self, the deep heart's core." (1986: 6) The following example supports the romantics' concept: 
(10) She had been the dream itself made flesh though the flesh I knew her in was not flesh itself but only a moving picture of flesh, real but not substantial (Había sido el sueño mismo hecho carne, aunque la carne que yo conocía de ella no era carne verdadera sino sólo una pelicula de carne, real pero no sustancial).

Richards was the first to baptize the two ideas active together in metaphor. $\mathrm{He}$ called them tenor and vehicle. The latter is "the idea conveyed by the literal meanings of the words used metaphorically," and the former is "the idea conveyed by the vehicle" (1936: 96):

$\begin{array}{lc}\begin{array}{c}\text { Object } \\ \text { (The item described) }\end{array} & \begin{array}{c}\text { Vehicle } \\ \text { (Image) }\end{array} \\ \text { leg of a person } \longrightarrow & \text { leg of a table } \\ \text { eye of a person } \longrightarrow & \text { eye of a needle } \\ \text { beast } \longrightarrow \text { he is a beast }\end{array}$

\author{
Tenor \\ (Ground of transfer) \\ functional similarity \\ formal similarity \\ evaluative similarity
}

For M. Blacks, a metaphor is not an isolated term, but a sentence. He calls the metaphorical sentence frame and the words used metaphorically focus or incongruent constituent: "the frame imposes extension of meaning upon the focal words" (1962: 39):

(11) "I'd forgotten the omniverous inscrutability of the sea, how it nibbles the earth with a mouth of water" (Ya no recordaba la inescrutabilidad omnivora del mar, cómo roe la tierra con una boca de agua). To understand this metaphor we need the frame of the sentence: the sea is the one which nibbles (roe la tierra).

Brooke-Rose defines metaphor as "any identification of one thing with another, any replacement of the more usual word or phrase by another" (1965: 17), as it happens in:

(12) "under a sky fissured with artificial fire" (bajo un cielo fisurado por un fuego artificial).

This is not the usual word both either in English or in Spanish.

\section{Types of metaphors}

Peter Newmark thinks that the purpose of a metaphor is "to describe an entity, event or quality more comprehensively and concisely and in a more complex way than is possible by using literal language," (1981: 84) and classifies it in five different types:

n dead metaphors are distinguished from others only in degree. They are lexicalized metaphors: the arm of the chair;

v cliché metaphors have already become automatic, not expressive at all because of excessive use: leave no stone unturned (no deja títere con cabeza);

- stock metaphors are very common, but they are not yet fossilized: a ray of hope;

v recent metaphors have not been used in the past. E.g.: Irangate. There are many in computer language: software, hardware, a word processor;

w original metaphors are poetic metaphors invented for a specific expression or occasion: The valley was embroidered with flowers.

Dagut does not agree with Newmark's classification, since "the use of such qualifying epithets as original metaphor (= metaphor stricto sensu) and dead metaphor (= polyseme or idiom), is really a confusing illusion. What such qualifiers do is to give the impression of a single metaphorical continuum made up of differing quantitative degrees of one and the same linguistic phenomenon... in actual fact, metaphor proper is qualitatively distinguished from its derivatives." (1987: 77) 


\section{TRANSLATABILITY OF METAPHOR FROM SL TO TL}

In spite of the lack of research on the subject of the translatability of metaphor, there are some studies by translation theorists about this question:

Kloepfer (1967) supports the simplistic approach, saying that there is no problem in translating metaphor; for instance in

(13) "There was a drugged smile on her face" (con una sonrisa drogada). Nevertheless, some structural changes have taken place in this translation:

\section{Transposition from finite clause $\longrightarrow$ prepositional phrase}

In the existential sentence (unstressed there) the thematic position is not empty but filled with a NP as $\mathrm{S}-$ she-preceding the $\mathrm{V}$ had (got). Thus the translation con instead of habia.

Kirsten Mason also writes that it is useless to establish a theory for metaphor translation: "there can only be a theory of translation; the problems involved in translating a metaphor are a function of problems involved in translating in general" (1982: 149).

Eugène Nida, and Vinay and Darbelnet insist that, on some occasions, it is not possible to translate a metaphor with another metaphor, for instance in

(14) "a late, ham-handed comedy" (una comedia más reciente, con un elenco lamentable).

A tentative scheme of modes of metaphor translation would show the following possibilities, in order of Newmark's preference (1981: 88):

- reproducing the same image in the TL;

- replacing the image in the SL, with a standard TL image;

- translating the metaphor by a simile;

- transferring the metaphor by simile plus sense;

converting the metaphor into sense.

Dagut (1987: 77) comments on Newmark's procedures insisting on the necessity "to distinguish clearly between metaphor proper" - what Newmark calls original metaphor - and such metaphorical derivatives as polysemes, idioms and proverbs - Newmark's dead metaphor. The relevance of this qualitative distinction to translation theory and practice is not far to seek: translating a given English polyseme, idiom or proverb is achieved by the selection of another, and the competent translator will only be really put to test in those cases where the TL system affords no equivalent to the particular SL item and the translator is therefore forced back on various substitution procedures, rendering the sense, but not the form, of the ST item. Hence, translation of metaphorical derivatives is essentially the same process as the translation of any other component of the SL system.

Some other theorists arrive at the same final conclusion about the intranslatability of metaphor between languages belonging to different families and rooted in different cultures:

- Menachem Dagut (1976, 1987) from English into Hebrew;

- Mary M. Y. Fung y K. L. Kiu (1987) from English into Chinese.

\section{THE CONTEXT OF METAPHOR}

\section{Literary translation}

Metaphor mainly occurs in literature, and the main difficulty of literary translation is that its form has deep roots in a specific language and culture: "every artist's work," writes Hall, "is conditioned by the limitations of the medium within which he works, by 
the cultural background in which he has grown up, and by the demands which his culture makes on him. Hence the literature written in any given language is of course channeled by the structure of the language." (1964: 406)

Literary translation may be defined - according to Toury - as "every literary text in the target literary system (and in the target linguistic system, since every literary text is a linguistic text), which is equivalent to another text in the source language." (1981: 11)

\section{The "New Paradigm" theory}

The most interesting approach to literary translation is the "New Paradigm" theory. It began in the middle of the "70s with an international group of scholars:

they have been attempting to break the deadlock in which the study of literary translation found itself;

- their approach differs in some fundamental respects from most traditional work in the field;

- the aim is quite simple - to establish a new paradigm system for the study of literary translation, on the basis of a comprehensive theory and ongoing practical research;

they have in common:

- a view of literature as a complex and dynamic system;

- a conviction that there should be a continual interplay between theoretical models and practical case studies;

- an approach to literary translation which is descriptive, target oriented, functional and systemic;

- they have an interest in:

- the norms and constraints that govern the production and reception of translations;

- the relation between translation and other types of text processing, and

- in the place and role of translation both within a given literature and in the interaction between literatures;

- this theory is based both on:

- linguistics (functional grammar and text linguistics), and

- literature (reception and polysystem theories).

\section{Linguistic, time, cultural and aesthetic claims} claims:

Literary translation - Selver (1986) says - is an art that must balance different

- The strictly linguistic claim on the translator, though of course it is a substancial one, is not the most pressing. In

(15) She seemed to be a little fox pretending to be a sirene, the non-finite -ing clause must be translated into a relative clause: Parecía un pequeño zorro que pretendía ser una sirena since the gerund is more restrictive in Spanish - it is only used in simultaneous clauses).

- There are also time claims: what was written some time ago necessarily requires different treatment by the translator than what was created only yesterday (the expression "passing by coach through a valley," will be translated differently if the text was written more than one century ago. We can't say autobús, but carruaje or diligencia), and there are cultural claims: no matter how simplistically some people may regard these matters, the differences between and among cultures are not simple and mechanistic, are not mere differences in the words by which the identical phenomena are described (we translate "Secretary Kissinger" by el Secretario de Estado...). 
The most important, and also the most difficult, claim to deal with is what might be termed the aesthetic claim; that is to say, how is the translator to reproduce in the new language the peculiar force and strength, the inner meanings as well as the merely outer ones, of what the original writer created solely and exclusively for and in a different language and a different culture. This is the claim imposed by metaphorical language. If the translator of a literary work has not done justice to the aesthetic claim, almost nothing else that he has done can possibly be worthy, as would happen with the following metaphoric expression:

(16) "Her laughter. The same as it had been at first, that unmuddled spring of freshness" (Aquella risa. La misma del principio, aquel limpido manantial de frescura).

Therefore, the relationship of the work translated and the translator's own work is a subtle and difficult one: "the translator — says Raffel and Burago (1972: 238) —, must be a careful investigator and an honest, sensitive critic, who can choose an author's basic characteristics and, when he needs to, can sacrifice to these characteristics others of less importance. He even must forget his own personality, must think only of the author's personality."

\section{TREATMENT OF METAPHOR BY TRANSLATION AS A RULE-GOVERNING ACTIVITY}

Source text-oriented theories of translation serve as a basis for translator's training, since they are concerned mainly with the act of translating potential translations and providing "translational norms as an intermediating factor between the system of potential equivalence relationships and the actual performance." (Toury 1981: 24) On the contrary, literary translation theory must be target text-oriented because it supplies a starting point or framework for a descriptive study of actual textual-linguistic products (instances of performance rather than competence). ference?

But, can we apply translation theory to the specific problems of metaphoric trans-

Having in mind all the previous theories, we are going to suggest some generalizations on metaphor translation. Thus, we have to analyse how metaphors are constructed, how they function in their context, inside the text they belong to. We shall use Angela Carter's The Passion of New Eve, since metaphorical language has a primary function in telling the story, and in conveying its meaning. As Peter Ackroyd (1977) says, in this book, "Carter's language is so grandiose and verbose it can only transmit fantasies and visions," as is the case in the following metaphorical appositions:

(17) I'd lost them by the time I left the desert, the domain of the sun, the arena of metaphysics, the place where I became myself (Las habia perdido cuando abandoné el desierto, el reinado del sol, la arena de la metafísica, el sitio en que llegué a ser yo misma).

It is, of course, beyond the scope of this study to discuss all the metaphors in the text; the wealth of figures to be dealt with would make this an impossible task for our purpose. We shall choose some examples which can be classified into five types:

Transferring the same image into the target language, provided the image has comparable frequency and currency in the appropriate register. This is suggested by Kloepfer and Mason, who defend a word-for-word translation of the already created metaphor from the source language: "translate the vehicle (in Richard's terminology) and the tenor will translate itself." This procedure is common for one-word metaphors, and the more universal the sense, the more likely the transfer:

(18) From these unnatural skies fell rains of gelatinous matter (caian lluvias de una sustancia gelatinosa). The Spanish version is more specific because of the determiner. 
Sometimes it is more difficult to reproduce one-word metaphors where the sense is an event or quality rather than entity:

(19) "She loitered among the confession magazines" (Se paseaba entre las revistas de confesiones).

If we make a componential analysis of the verb loiter we can see that a lot of semes have been lost:

\begin{tabular}{|lccccc|}
\hline & move & walk & waste time & idle & fall behind \\
\hline loiter & + & + & + & + & + \\
\hline pasear & + & + & - & - & - \\
\hline
\end{tabular}

We suggest se entretenia, for instance, which include those three specific semes, absent in pasear.

Transfer of complex metaphors is much rarer and depends on cultural overlap. The following examples are word-for-word translations:

(20) "She, fleshy synthesis of the dream, both dreamed and dreamer" (sintesis carnal del sueño, soñada y a la vez soñadora). It can be translated literally into Spanish because of our language and cultural proximity.

(21) ...into the diabolic cleft of the night (hacia el hueco diabólico de la noche).

Modulation from more specific to more general.

(22) "Tristessa, the very type of romantic dissolution, necrophilia incarnate" (Tristessa, el alma misma de la disolución romántica, la encarnación de la necrofilia).

Modulation from more general to more specific:

(23) She was entirely the creature of this undergrowth (Era la hija de aquella espesura).

Metonymic transfer: whole $\rightarrow$ part

Angela Carter feels a preoccupation with the body, the human body, and sometimes gets a sense of the city as a body:

(24) That the city had become nothing but a gigantic metaphor for death (El hecho de que la ciudad no fuese ahora sino una vasta metáfora de la muerte)

There are some structural changes:

a transposition (change of polarity), the negation passes from the $\mathrm{O}$ to the $\mathrm{V}$;

ine resulting copula $\longrightarrow$ current copula;

- the modulation: from specific to general, and the metaphor of the modifier gigantic is translated by its sense vasta.

The image of the city turns up in her work over and over again.

(25) A wasted, inner-city moon... leaked a few weak beams upon my prey (Una luna consumida, de ciudad interior... vertía unos pocos rayos débiles sobre mi presa).

Transposition: the pre-modifier, adjectival phrase $\longrightarrow$ postmodifier, prepositional phrase. 
Modulation (aspectual): inner is pejorative and interior neutral. There is also a change of meaning in interior.

Leaked does not have direct correspondence with vertia, since the former means to let pass through a hole or crevice and the latter means throw.

(26) In "The geometric labyrinth of the heart of the city" (el laberinto geométrico del corazón de la ciudad), a word-for-word translation, the metaphorical term heart is already lexicalized, but it becomes an original metaphor when Angela Carter adds a modifier to it:

(27) The megalopolitan heart that did not beat any more (el corazón megalopolitano que ya habia dejado de latir).

All the previous metaphors were rendered with by their literal equivalents in Spanish. On the contrary, there are cultural voids that have no cultural correspondence. They are words defining some part of the source language specific culture for which, because of their disparity, there is no one-word equivalent in the target language:

(28) In "chewing a stick of candy - a Baby Ruth...," the best way to deal with it is to transcribe it in the actual target text: "mascando un palillo de caramelo, un Baby Ruth..." and, if necessary, to explain the term in a footnote or to append a glossary at the end. This preserves the cultural authenticity of the source language and enables the reader to see the genuine expression of the original.

Adaptation of the same image that appears in source language. This is the obvious way of modifying the shock a metaphor can produce in the target language, particularly if the target text is not emotive in character. This procedure can be used to modify any type of word, as well as original complex metaphor: In the case of

(29) "New York has become the City of Dreadful Night" (Ciudad de los terrores nocturnos), we simply have to adapt a most suitable form, without changing the image of the metaphor. As we can see, Angela Carter presents New York as a kind of huge, decaying body while she considers the city a very strong metaphor.

The same structural changes we have observed on tranferring an image from the source language to the target language are evident when it is necessary to adapt this image: in the following example, there is modulation from product to object/instrument:

(30) In "Sometimes he talked about the death camps, and how the Gestapo raped his wife" (campos de exterminio), we have to choose a lexical item admitted in the target language.

Re-creation in the target language of a different metaphor, which is considered by Dagut as the special problem of translating metaphor proper. In his own words:

The metaphor in the ST, being by definition a creative violation of the SL semantic system, has to be created in the TT, since its equivalent obviously cannot be found in the TL system (1987: 78).

Thus, the translator will have to re-create the metaphor in the TL if we do not accept the untested and improbable assumption that all metaphors are universal and, therefore, it is sufficient for a metaphor to be acceptably and effectively used in one language to ensure its equal acceptability and effectiveness when literally transferred to any other language:

(31) Her swimming eyes (Sus ojos flotantes). 
According to Mason, "each occurrence of a metaphor for translation must be treated in isolation: each of its components must be dealt with in the light of its cultural connotations before a translation of the whole can take place, and account must also be taken of the textual context in which the metaphor is used." (1982: 149) Culturally specific metaphors have to be treated quite differently, precisely because its function is not to denote a cultural referent. In the following example, we do not simply have to adapt the metaphor, but to create a new one:

(32) In "When they heard my cut-glass vowels of an East Coast university," we do not simply have to adapt the metaphor. On the other hand, transcription would be totally incomprehensible to the target language reader, with the context providing no clues as to its meaning, and explanatory additions not conveying any of the emotional force of the source language to the reader. Thus, the translator has to recreate a new metaphor: "Cuando oyeron mis vocales cristalinas."

Or the following example:

(33) "it kept me all agog in my ring-side seat" (me mantenía paralizado de ansiedad, pegado a mi butaca junto al cuadrilátero).

"Culturally specific metaphors are untranslatable" - Dagut states - "it is not possible either to paraphrase or to explain them, and their transference word-for-word will distort the source language, since the cultural reference of the term is not their main reason." (1987: 80) Thus, the cultural content is not important in its own right, but only as the vehicle of metaphor.

Translation of metaphor by simile plus sense. According to Newmark (1981: 88), while this is always a compromise procedure, it has the advantage of combining communicative and semantic translation in addressing itself both to the layman and the expert if there is a risk that the simple transfer of the metaphor will not be understood by most readers:

(34) She is a fox (es tan astuta y aguda como un zorro).

Translation of metaphor by its sense. Depending on the type of text, this procedure is common, and is to be preferred to any replacement of an SL by a TL image which is too wide of the sense or the register (including here current frequency, as well as the degrees of formality, emotiveness and generality, etc.). In poetry translation, compensation in a nearby part of the text may be attempted; but to state that in poetry, any metaphor must always be replaced by another is an invitation to inaccuracy and can only be valid for original metaphors.

A case of compensation may be the following example: "... to scurry back, quick as I could, to festering yet familiar London, the devil I knew" (... de vuelta a Londres, lo más rápido posible, a la ciudad emponzoñada pero familiar, el demonio conocido). The proper noun London is not repeated in the apposition but a synonym.

Actually, when a metaphor is converted into sense, the sense must be analysed componentially, since the essence of an image is that it is pluridimensional - otherwise literal language would have been used. Further, the sense of an image will usually have an emotive as well as a factual component, an element of exaggeration which will be reduced in the translation in inverse ratio to the liveliness of the metaphor.

Thus we can translate

(35) "She is as good as gold" (posee las mejores cualidades), and in 
(36) "All these absurd notions flickered through my injustice as I tore hell-for-leather through the night" (me precipitaba desgarrando); the translator has chosen to change the metaphor into its meaning.

(tore is not used in its literal sense; thus the translation could have been "Corría como el demonio" or simply "Me precipité a toda velocidad").

In fact, without metaphorical language a work of literature turns into another kind of text - certainly never intended by its original author - this detracts from the readability of the work and thus does an injustice to the author (as well as it presumably reduces the number of readers of the translation); the same happens in:

(37) So she led me deep into (Así me arrastró hasta internarme en).

\section{Modulation from concrete to abstract:}

The conversion of a metaphor or a simile to their sense can be considered a deletion. There is a case for its deletion, together with its sense component, provided the SL text is not authoritative or expressive (that is, primarily an expression of the writer's personality). A decision of this nature can be made only after the translator has weighed up what he thinks is more important and what is less important in the text in relation to its intention.

\section{CONCLUSION}

We may conclude by saying that when we examine metaphor within its immediate context, it reveals that the metaphoric process is not only the substitution of a lexical term from one semantic domain for a term from another, but there are also other internal relationships within the larger context of the entire text: the narrative framework also comes into play and orientates our interpretation. This happens mainly when we analyse Angela Carter's tale, full of old myths and symbols that relate to each other throughout the story. An example may be this original metaphor that defines her heroine's character:

(38) "I used to adore to watch her dressing herself... in her craket mirror, the tranformation of the grubby little bud... she was a night-blooming flower" (Me fascinaba observarla cuando se engalanaba por las noches... en el espejo cuarteado, la metamorfosis de aquel capullo agusanado... era una flor que se abria de noche). We need to identifie Carter's theme of the mirror as a symbol, and to change the tradition which applied to it the meaning of woman's vanity for that of the heroine seeing herself reflected as an object, a sight that discovers her own identity. The identification of the purpose of metaphor, then, is necessary if the translator wants to interpret the story properly, since the translatability of metaphor in concrete texts will depend on the relations into which it enters with the other elements on various levels.

What we have mainly attempted is to show that certain generalizations can be made about the process of translating metaphor. Since theory is concerned with discovering regularities and should not try to create them by imposing rules or norms on translational practice, we have tested the cases that helped our purpose, both in the source and in the target language, and have got these results:

In Angela Carter's The Passion of New Eve, metaphors have been translated in the following modes: 1) by transferring the same image into the target language, in more than fifty percent of all cases, because of the proximity of the two systems; 2) by adapting the same image that appears in source language, in about ten percent of cases: the structure of every language demands an adaptation in some cases; 3 ) by re-creating in the target language a different metaphor, in twenty percent of cases; this derives from the cultural voids between languages that have no possible word-for-word equivalent; 4) there are 
few cases of translating metaphors or similes by their sense. That means that the translator has paid due attention to the aesthetic claim of the text and has tried to offer a version according to the author's purpose. In Angela Carter, meaning is interweaved with form; if the translator had ignored the metaphorical language, the result would have been a bad translation.

We hope that this explanation, in that it brings a tentative description of how and to what extent metaphors can be translated, has in a sense contributed to clarifying what a theory of literary translation can actually try to achieve.

\section{REFERENCES}

On metaphor translation

DAGUT, M. (1976): "Can Metaphor Be Translated?", Babel, 32-1, pp. 22-33.

DAGUT, M. (1987): “More About the Translatability of Metaphor", Babel, 33-2, pp. 77-84.

MASON, K. (1982): "Metaphor and Translation", Babel, 28-3, pp. 140-149.

NEWMARK, P. (1981): Approaches to Translation, Oxford, Pergamon Press.

RAFFEL, B. and V. J. CLEARY (1973): Why Re-Create?, San Francisco, Chandler and Sharp.

SELVER, P. (1986): The Art of Translating Poetry, London, Jon Baker.

TOURY, G. (1981): "Translated Literature: System, Norm, Performance", Poetics Today, 2-4, pp. 9-27.

VINAY, J.-P. and J. DARBELNET [1977](1958): Stylistique comparée du français et de l' anglais, Paris, Didier.

On metaphor theory

AARTS, J. M. G. (1977): Metaphor and Non-Metaphor: The Semantics of Adjective-noun Combinations, Tübingen, Max Niemeyer.

ALVAREZ DE MIRANDA, A. (1963): La metáfora y el mito, Madrid, Taurus.

ARISTOTLE (1984): Poetics (trad. I. Bywater), in The Rhetoric and the Poetics of Aristotle, New York, Modern Library.

BERGER, J. [1977](1972): Ways of Seeing, London, Penguin Books.

BICKERTON, D. (1969): "Prolegomena to a Linguistic Theory of Metaphor", FL, 5, pp. 34-52.

BLACK, M. (1954-1955): “Metaphor!", Proceedings of the Aristotelian Society, 55, pp. 273-294.

BLACK, M. (1962): Modes and Metaphors: Studies in Language and Philosophy, Ithaca, Cornell University Press.

BLACK, M. [1981](1978): "How Metaphors Work: a Reply to Donald Davidson", On Metaphor, S. Sacks (Ed.), Chicago \& London, The University of Chicago Press.

BOOTH, W. C. [1981](1978): "Metaphor as Rhetoric: The Problem of Evaluation", On Metaphor, S. Sacks (Ed.), Chicago \& London, The University of Chicago Press.

BROOKE-ROSE, Ch. (1965): A Grammar of Metaphor, London, Secker \& Warburg.

COHEN, T. [1981](1978): "Metaphor and the Cultivation of Intimacy", On Metaphor, S. Sacks (Ed.), Chicago \& London, The University of Chicago Press.

COOPER, D. E. (1986): Metaphor, Oxford, Basil Blackwell

DAVISON, D. [1981](1978): "What Metaphors Means", On Metaphor, S. Sacks (Ed.), Chicago \& London, The University of Chicago Press.

FUNG, M. M. Y. and K. L. KIU (1987): "Metaphor Across Language and Culture", Babel, 33-2.

GARCIA DIEZ, M. A. (1983): La metáfora y sus relaciones con la metonimia, la sinécdoque y la comparación, Oviedo, Walfer.

GARDNER, H. and E. WINNER [1981](1978): "The Development of Metaphoric Competence: Implications for Humanistic Disciplines", On Translation, S. Sacks (Ed.), Chicago \& London, The University of Chicago Press.

HALL, R. A. (1964): Introductory Linguistics, Philadelphia, Chilton.

HARRIS, K. [1981](1978): "Metaphor and Transcendence", On Metaphor, S. Sacks (Ed.), Chicago \& London, The University of Chicago Press.

HARRIS, K. [1981](1978): "The Many Uses of Metaphor", On Metaphor, S. Sacks (Ed.), Chicago \& London, The University of Chicago Press.

HENRY, A. (1971): Métonymie et métaphore, Paris, Klincksieck.

KITTAY, E. F. ( 1987): Metaphor: Its Cognitive Force and Linguistic Structure, Oxford, Clarendon Press.

KLOEPFER, P. (1967): Die Theorie der literarischen Übersetzung, citado por M. Dagut (1987), op.cit.

KURZ, G. (1982): Metaphor, Allegorie, Symbol, Göttingen, Vandenhoeck \& Ruprecht.

LAKOFF and JOHNSON (1980): Metaphors We Live By, Chicago, The University of Chicago Press.

LE GUERN, M. (1976): La metáfora y la metonimia (trad. A. Gálvez-Cañero), Madrid, Cátedra.

MAC CORMAC, E. R. (1985): A Cognitive Theory of Metaphor, Cambridge, Mass. (A Bradford Book), The MIT Press. 
NIDA, E. A. and REYBURN, W. D. (1981): Meaning Across Cultures, New York, Orbis Books.

QUINE, W. V. [1981](1978): "A Postcript on Metaphor", On Metaphor, S. Sacks (Ed.), Chicago \& London, The University of Chicago Press.

RAFFEL, B. and BURAGO, A. (Eds. \& trans.) (1972): Selected Works of Nikolai S. Gumilev, Albany, State University of New York Press.

RICHARDS, I. A (1936): Philosophy of Rhetoric, London, Oxford University Press.

RICOEUR, P. (1980): La metáfora viva (trad. del francés Agustin Neira), Madrid, Europa.

RICOEUR, P. [1981](1978): "The Metaphorical Process as Cognition, Imagination, and Feeling", On Metaphor, S. Sacks (Ed.), Chicago \& London, The University of Chicago Press.

RORTY, R. (1986): "The Contingency of Language", London Review of Books, April 17, pp. 3-6.

SHIBLES, W. A. (1971): Metaphor: An Annotated Bibliography and History, Whitewater, Wisconsin, The Language Press.

SHIFF, R. [1981](1978): “Art and Life: A Metaphoric Relationship", On Metaphor, S. Sacks (Ed.), Chicago \& London, The University of Chicago Press.

SWANSON, D. R. [1981](1978): "Towards a Psychology of Metaphor", On Metaphor, S. Sacks (Ed.), Chicago \& London, The University of Chicago Press.

TATO C. -ESPADA, J. L. (1975): Semántica de la metáfora (Estudio introductorio), Alicante, Instituto de Estudios Alicantinos, Diputación Provincial de Alicante (Patronato José María Quadrado del CSIC).

TURBAYNE, C. M. (1974): El mito de la metáfora, trad. C. Pacheco, México, Fondo de Cultura Económica.

\section{On Angela Carter}

ACKROYD, P. (1977): "Angela Carter", Spectator, March 26.

CARTER, A. [1982](1977): The Passion of New Eve, London, Virago.

CARTER, A. (1982): La pasión de la nueva Eva, trad. M. Horne, Barcelona, ediciones Minotauro EDHASA.

CARTER, A. (1982): Nothing Sacred: Selected Writings, London, Virago.

CARTER, A. (1983): "Notes from the Front Line", On Gender and Writing, M. Wandor (Ed.), Pandora. 